\title{
Branchial Chamber and Gastrointestinal Tracts Parasites of Fish Species in Benue and Niger Rivers, North Central, Nigeria
}

\author{
Agatha Eleojo Onoja-Abutu, ${ }^{1}$ Martin Abdubala Okpanachi, ${ }^{2}$ Luay Alkazmi, ${ }^{3}$ \\ Clement Ameh Yaro $\mathbb{D}^{4}{ }^{4}$ and Gaber El-Saber Batiha ${ }^{5}$ \\ ${ }^{1}$ Department of Biology, Kogi State College of Technical, Kabba, Kogi State, Nigeria \\ ${ }^{2}$ Department of Animal and Environmental Biology, Kogi State University, Anyigba, Kogi State, Nigeria \\ ${ }^{3}$ Biology Department, Faculty of Applied Sciences, Umm Al-Qura University, Makkah 21955, Saudi Arabia \\ ${ }^{4}$ Department of Animal and Environmental Biology, University of Uyo, Uyo, Akwa Ibom State, Nigeria \\ ${ }^{5}$ Department of Pharmacology and Therapeutics, Faculty of Veterinary Medicine, Damanhour University, Damanhour 22511, \\ AlBeheira, Egypt
}

Correspondence should be addressed to Clement Ameh Yaro; yaro.ca@uniuyo.edu.ng

Received 27 November 2020; Revised 21 January 2021; Accepted 25 February 2021; Published 5 March 2021

Academic Editor: Edson Gandiwa

Copyright (c) 2021 Agatha Eleojo Onoja-Abutu et al. This is an open access article distributed under the Creative Commons Attribution License, which permits unrestricted use, distribution, and reproduction in any medium, provided the original work is properly cited.

Freshwater fish species are posing health challenges by either serving as host of parasites that are harmful to man and animals. This study was conducted to determine the parasitic profile of the branchial and gastrointestinal tracts of freshwater fish species from Niger and Benue rivers at Lokoja. These fish species are Tilapia zillii, Oreochromis niloticus, Clarias species, Synodontis schall, and Megalops atlanticus. Fish samples were collected within a period of 12 months, and the species and sex of the fish were identified. The two opercula of each fish were removed and examined for parasites; parasites recovered were preserved in $0.7 \%$ physiological saline. Gastrointestinal tracts were removed from each fish, placed in physiological saline, and examined microscopically for parasites. Prevalence of parasites was calculated. The chi-square test was used to compare prevalence of parasites according to sexes, body parts examined, fish species, and parasites species, while the $t$-test was used to compare between gills and intestines of each fish species. The chi-square test was used to determine if any significant difference exists in prevalence between the sexes, body parts, fish species, and parasites species, while the $t$-test was used to determine if any significant difference exists in prevalence between the gills and intestines of each fish species. A total of seven parasites species were harboured in branchial chamber and gastrointestinal tracts of fish species from rivers Niger and Benue: Clinostomum sp. (trematode), Camallanus sp. (nematode), Capillaria sp., Rhabdochona congolensis (nematode), Contracaecum sp. (nematode), Proteocephalus sp. (cestode), and Spinitectus guntheri. T. zillii (81 (95.3\%)) had the highest prevalence, while O. niloticus, Clarias sp., S. schall, and M. atlanticus had prevalence of $87(89.7 \%), 96(80.0 \%), 48(70.6 \%)$, and 27 (38.6\%), respectively. Out of the total fish samples examined, females (191 $(80.3 \%))$ were observed to harbour more parasites than males $(148(73.3 \%))$. The gastrointestinal tracts $(287(65.2 \%))$ significantly harboured more parasites than branchial chamber $(52(11.8 \%)$ ). Fish species in rivers Niger and Benue are highly infected with parasites. Fish consumers should subject the fish to proper processing before consumption, as some of these parasites are of zoonotic importance.

\section{Background}

Freshwater environments are exceedingly biodiverse. Freshwater constitutes only $0.8 \%$ of the earth' surface area with approximately $0.02 \%$ of the habitable volume of the Earth and contains about $30 \%$ of vertebrate species [1-3].
The freshwater is essential to human life, leading to humans traditionally dwelling along rivers and wetlands. This proximity of people to these water bodies constitutes declines in freshwater species and quality $[4,5]$. The IUCN [6] reported that $24.6 \%$ of freshwater species are threatened, while $27.0 \%$ fish species is threatened. Series of factors such 
as habitat loss, pollution, invasive species, over exploitation, and climate change are responsible for this loss in the freshwater biodiversity and quality $[7,8]$. These factors affect the fish species biodiversity and parasite fauna of freshwater environments. Also, the spatial and temporal variability of intermittent rivers is likely to have a major influence on parasite diversity and abundance and on the dynamics of parasitic diseases because of their direct effects on parasite free-living stages and indirect effects on freshwater fishes [3].

Fish are rich source of protein to man and other animals. They contain lipids, mineral oils, and vitamins which have a remarkable impact on the lives of many individual and communities $[9,10]$. Fish oils are known to contain omega-3 essential fatty acid which helps for the proper functioning of the brain, heart, and immune system [11]. Fishes interact at the various levels of food chain, thereby influencing the habitat structure [9]. Despite their significance to man, freshwater fish species are known for harbouring parasitic organisms by either serving as intermediate or definitive host of parasites which are harmful to man and animals [12]. These parasitic protozoans and helminths are known to affect the health, growth, and survival of the fish while causing nutrient devaluation, alteration in biology and behaviour, lowering of the immune system, blindness, morbidity, mortality, fecundity reduction, and mechanical injuries [13].

Nigeria is blessed with many freshwater bodies of which rivers Niger and Benue are the two major freshwater bodies cutting across the country from north to south. Series of studies have been conducted on parasites of freshwater fish species in different parts of the Nigeria [14-20]. Little or no study was conducted on the parasites of the branchial chamber of freshwater fish. This study was conducted to investigate the parasitic profile of the branchial and gastrointestinal tracts (GIT) of freshwater fish species from Niger and Benue rivers at Lokoja.

\section{Methods}

2.1. Study Area. The study was carried out in Lokoja, Kogi State, Nigeria. It lies between latitude $7^{\circ} 40^{\prime} \mathrm{N}-8^{\circ} 10^{\prime} \mathrm{N}$ and longitude $6^{\circ} 40^{\prime} \mathrm{E}-7^{\circ} 10^{\prime} \mathrm{E}$. Lokoja is a city situated at the confluence of Niger and Benue rivers having extensive flood plains with numerous perennial ponds and marshes on both banks of the rivers before and within the confluence. The vegetation along the rivers comprises mainly of wooded savannah grassland with shrubs and trees. The climate of the area consists of two seasons, the dry season and wet season. The wet season begins toward the end of March and ends towards the end of October or early December, while the dry season begins in November and lasts until late march. The annual rainfall ranges between $1016 \mathrm{~mm}$ and $1700 \mathrm{~mm}$ and mean daily temperature ranges between $25^{\circ} \mathrm{C}$ and $29^{\circ} \mathrm{C}$ [21]. Three (3) sampling sites were selected along the rivers: Irenedu village-along LokojaKoton-Karfe road (Niger River), Mozum village-located on the eastern bank (Benue River), and Chintaco village-downstream of the confluence (Figure 1).
2.2. Ethical Approval and Consent to Participate. This study follows guidelines for the care and use of experimental animals established by the Animal Care and Use Committee of the Kogi State University, Anyigba, Nigeria, for the purpose of control and supervision of experiments on animals.

2.3. Collection of Fish Samples. Fish samples were collected within a period of 12 months (May 2019-April 2020), with the aid of artisanal fishers using cast and gill nets of various mesh sizes. The fish were collected on ice and transported to the laboratory for subsequent analysis. The fish samples were identified using texts standard keys [22, 23].

2.4. Sex Determination. The sex of each fish was determined by physical observation of the urogenital papillae. It is long or distended in male, while in female, it is round and reddish in the matured ones. The sex was confirmed by internal examination after dissection to expose the paired testes in the males and paired ovaries in the females [24].

2.5. Examination of Fish for Parasites. The two opercula of each fish were removed, and their inner sides were examined under the dissecting microscope. Recovered parasites were placed in $0.7 \%$ physiological saline; thereafter, the gills were dissected out, placed in Petri dish containing physiological saline, and examined with the aid of a dissecting microscope. Parasites found were noted, removed, and preserved in $4 \%$ formalin for further identification and classification.

The GIT was removed from each fish and placed in a Petri dish containing physiological saline for examination as stated above.

2.6. Identification of Parasites. The detected parasites were identified according to their morphology using a stereomicroscope. Standard keys for identification of fish parasites were used $[25,26]$.

2.7. Statistical Analysis. Prevalence of parasites was estimated through the following formula:

$$
\text { Prevalence }(\%)=\frac{\text { Number of fish host infected }}{\text { Total number of fish host examined }} \times 100 \text {. }
$$

The chi-square test was used to determine if any significant difference exists in prevalence between sexes, body parts, fish species, and parasites species, while the $t$-test was used to determine if any significant difference exists in prevalence between the gills and intestines of fish species examined. Analysis was performed using the Statistical Package for Social Science version 21.0 (SPSS Inc., Chicago, IL) at $p \leq 0.05$. 


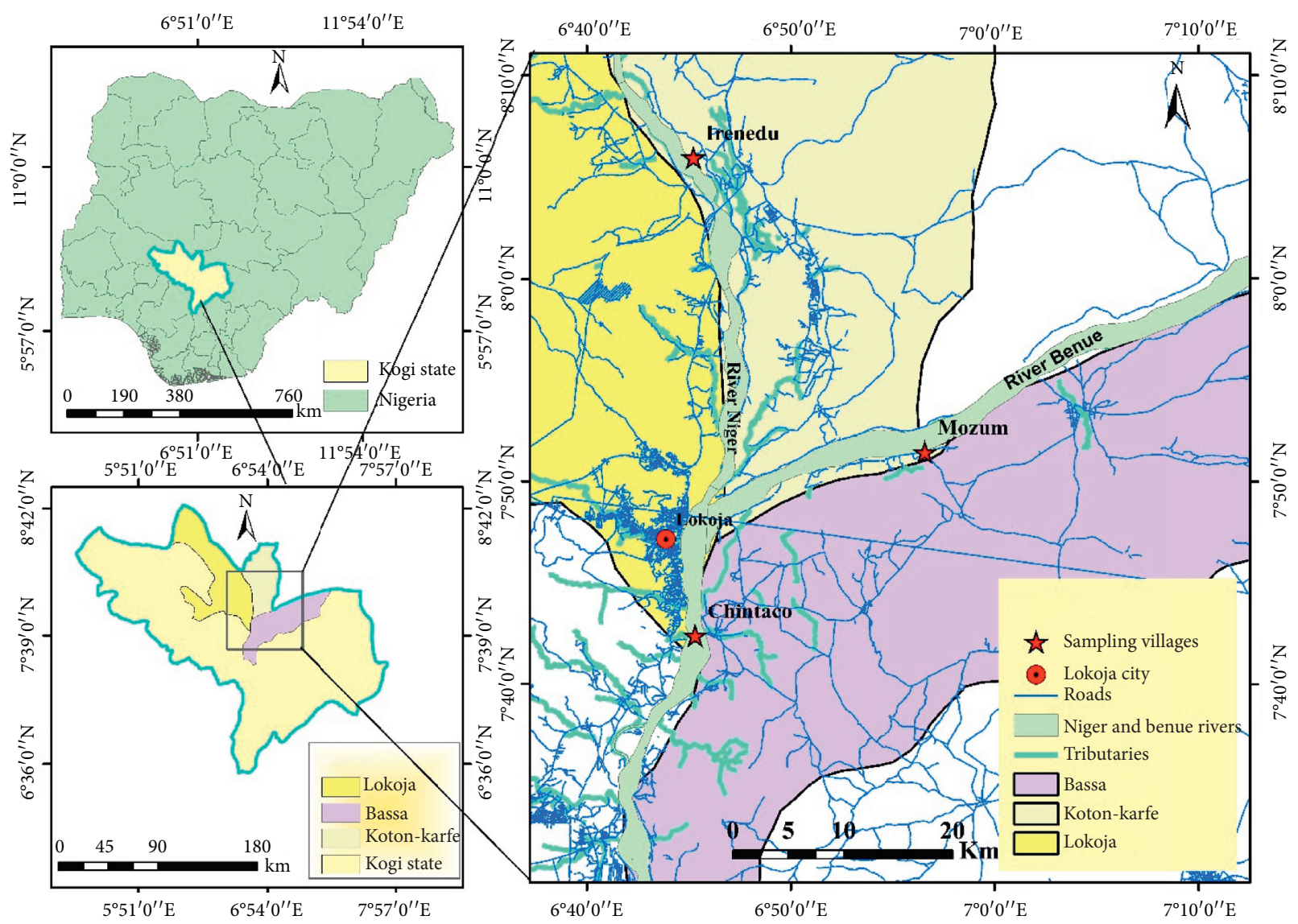

FIgURE 1: Map of sampling villages in the study area. Source: GIS unit, Geography Department, Kogi State University, Anyigba.

\section{Results}

3.1. Prevalence of Parasites in Fish Species in Rivers Niger and Benue, Lokoja. A total of seven (7) parasites species were found in five (5) fish species (Clarias sp., Tilapia zillii, Oreochromis niloticus, Synodontis schall, and Megalops atlanticus) examined from rivers Niger and Benue at Lokoja. These parasites were Clinostomum sp. (trematode) (Figure 2(a)), Camallanus sp. (nematode) (Figure 2(b)), Capillaria sp. (nematode) (Figure 2(c)), Rhabdochona congolensis (nematode) (Figure 2(d)), Spinitectus guntheri (Figure 2(e)), Contracaecum sp. (nematode) (Figure 2(f)), and Proteocephalus sp. (cestode) (Figure 2(g)).

A total of 440 fish samples were examined for parasites from both rivers. A total of 339 (77.0\%) were observed to harbour parasites. Tilapia zillii harboured the highest number of parasites with a prevalence of 81 (95.3\%), followed by Oreochromis niloticus (87 (89.7\%)), Clarias sp. (96 $(80.0 \%))$, and Synodontis schall (48 (70.6\%)), while Megalops atlanticus $(27(38.6 \%))$ harboured the least parasites (Table 1). Comparison of the prevalence among the fish species examined revealed a significant difference $(p \leq 0.05)$.

Comparison of parasites harboured by the fishes revealed a significant difference $(p \leq 0.05)$ in their occurrence. Contracaecum sp. (18.0\%) was the most prevalent parasite followed by Camallanus sp. (12.5\%), Capillaria sp. (10.5\%), R. congolensis (8.6\%), and Clinostomum sp. (8.2\%), while Proteocephalus sp. (4.1\%) was the least prevalent (Table 2).
In terms of the occurrence of the various parasites in fish species examined, Contracaecum sp. was the most prevalent parasite in Clarias sp. (23.3\%), O. niloticus (21.8\%), S. guntheri (27.1\%) in T. zillii and S. schall (17.6\%), while Camallanus sp. and $S$. guntheri had equal prevalence of $10 \%$ in $M$. atlanticus. Proteocephalus sp. was the least occurring fish parasite in all the fish species examined, Clarias sp. (5.8\%), T. zillii (3.5\%), O. niloticus (6.2\%), S. schall (2.9\%), and M. atlanticus (0.0\%) (Table 3). Comparison of the prevalence of parasites in individual fish species revealed a significant difference $(p \leq 0.05)$ in Clarias sp., T. zillii, O. niloticus, and S. schall, while there was no significant difference $(p>0.05)$ in M. atlanticus (Table 3).

3.2. Sex-Specific Prevalence of Parasites in Fish Species. The occurrence of parasites in sexes of fish species examined is presented in Table 4. Overall sex-specific prevalence of the parasites in the fish species examined revealed no significant difference $(p>0.05)$. Females had a prevalence of $80.3 \%$ (191 fish) higher than males with prevalence of $73.3 \%$ (148 fish) (Table 4). In Clarias sp., 32 (66.7\%) males and 64 (88.9\%) females harboured parasites, and the comparison between sexes revealed a significant difference $(p \leq 0.05)$ in this species. There was no significant difference between sexes of T. zillii, O. niloticus, S. schall, and M. atlanticus, 42 (95.5\%) males and 39 (95.1\%) females in T. zillii, 44 (88.0\%) males and 43 (91.5\%) females in O. niloticus, 32 (62.5\%) males and 36 (77.8\%) females in S. schall, and 10 (35.7\%) males and 17 (40.5\%) females in M. atlanticus. 


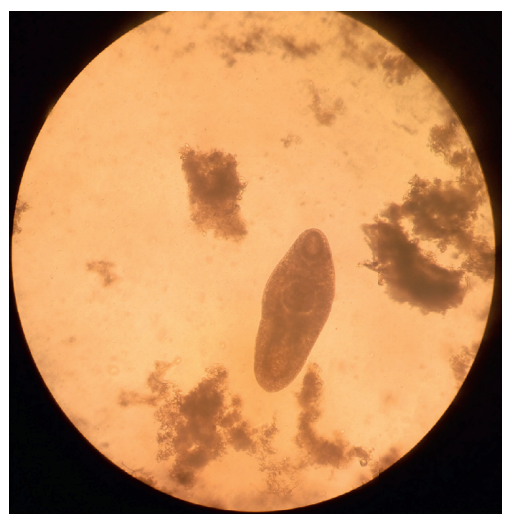

(a)

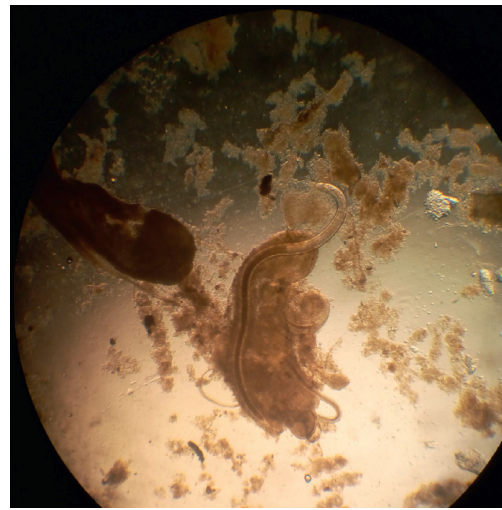

(d)

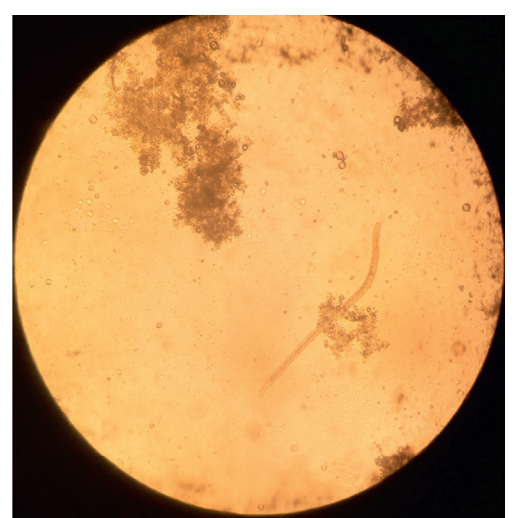

(b)

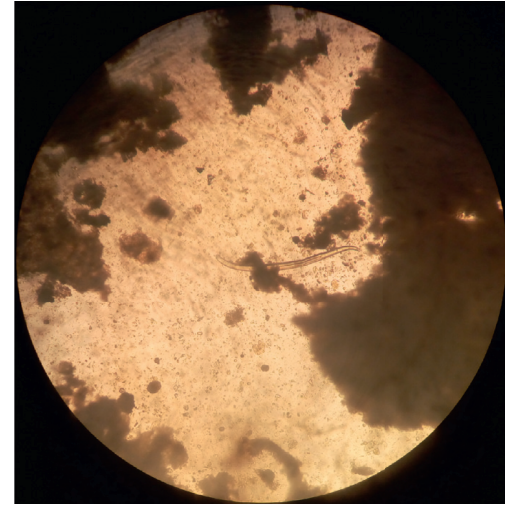

(e)

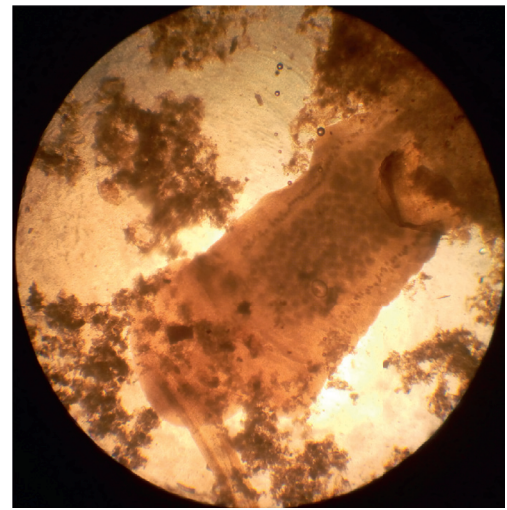

(g)

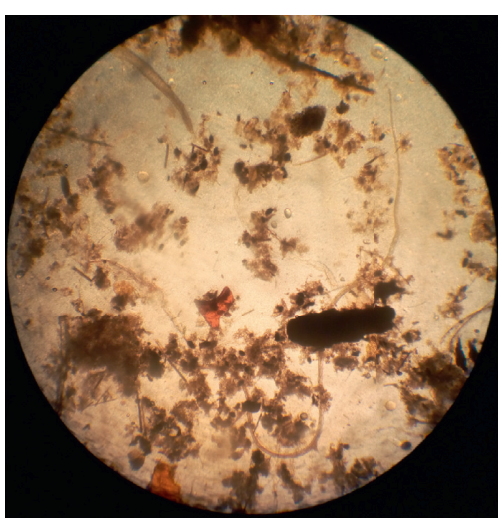

(c)

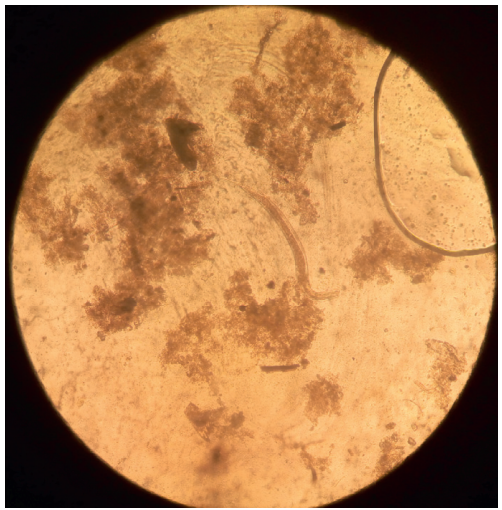

(f) (nematode), (c) Capillaria sp. (nematode), (d) Rhabdochona congolensis (nematode), (e) Spinitectus guntheri, (f) Contracaecum sp. (nematode), and (g) Proteocephalus sp.

Table 1: Prevalence of parasites of fish species in rivers Niger and Benue at Lokoja.

\begin{tabular}{|c|c|c|c|c|c|c|}
\hline Fish species & Number examined & Number positive (\%) & Number negative (\%) & Chi-square & df & $p$ value \\
\hline Clarias sp. & 120 & $96(80.0)$ & $24(20.0)$ & \multirow{6}{*}{85.560} & \multirow{6}{*}{4} & \multirow{6}{*}{$<0.001^{*}$} \\
\hline Tilapia zillii & 85 & $81(95.3)$ & $4(4.7)$ & & & \\
\hline Oreochromis niloticus & 97 & $87(89.7)$ & $10(10.3)$ & & & \\
\hline Synodontis schall & 68 & $48(70.6)$ & $20(29.4)$ & & & \\
\hline Megalops atlanticus & 70 & $27(38.6)$ & $43(61.4)$ & & & \\
\hline Total & 440 & $339(77.0)$ & $101(23.0)$ & & & \\
\hline
\end{tabular}

*Significant at $p \leq 0.05$. 
Table 2: Parasites in fish species in rivers Niger and Benue at Lokoja.

\begin{tabular}{|c|c|c|c|c|c|c|}
\hline Parasites & Number of fish examined & Number positive (\%) & Number negative (\%) & Chi-square & $\mathrm{df}$ & $p$ Value \\
\hline Clinostomum sp. & 440 & $36(8.2)$ & $404(91.8)$ & \multirow{8}{*}{58.418} & \multirow{8}{*}{6} & \multirow{8}{*}{$<0.001^{*}$} \\
\hline Camallanus sp. & 440 & $55(12.5)$ & $385(87.5)$ & & & \\
\hline Capillaria sp. & 440 & $46(10.5)$ & $394(89.5)$ & & & \\
\hline Rhabdochona congolensis & 440 & $38(8.6)$ & $402(91.4)$ & & & \\
\hline Contracaecum sp. & 440 & $79(18.0)$ & $361(82.0)$ & & & \\
\hline Proteocephalus sp. & 440 & $18(4.1)$ & $422(95.9)$ & & & \\
\hline Spinitectus guntheri & 440 & $67(15.2)$ & $373(84.8)$ & & & \\
\hline Total & 440 & $339(11.0)$ & $2741(89.0)$ & & & \\
\hline
\end{tabular}

* Significant at $p \leq 0.05$.

3.3. Prevalence according to Body Parts Examined. Comparison of the prevalence of gills infected with parasites to that of the intestines revealed a highly significant difference $(p \leq 0.05)$ in all the fish species. In all the fish species observed, the intestines harboured more parasites than the gills. A total of 287 (65.2\%) intestines had parasites, while 52 $(11.8 \%)$ gills had parasites. In the fish species, $68.3 \%, 78.8 \%$, $77.3 \%, 58.8 \%$, and $32.9 \%$ intestines and $11.7 \%, 16.5 \%, 12.4 \%$, $11.8 \%$, and $5.7 \%$ gills in Clarias sp., T. zillii, O. niloticus, $S$. schall, and $M$. atlanticus harboured parasites, respectively (Table 5).

3.4. Prevalence of Parasites according to Sample Locations. Fish samples were collected from three different landing sites along rivers Niger and Benue at Lokoja, Chintaco, Irenedu, and Mozum. Fish samples from Mozum had the highest prevalence of $79.3 \%$ (115 fishes), followed by those from Irenedu with $78.2 \%$ (111 fish), while those from Chintaco had the least with $73.9 \%$ (113 fish). There was no significant difference $(p>0.05)$ in the prevalence of parasites among the locations (Table 6).

In terms of the fish species, T. zillii harboured the highest number of parasites in the three locations, Mozum (96.8\%), Chintaco (96.4\%), and Irenedu (92.3\%), while M. atlanticus harboured the least number of parasites in the three locations with prevalence of 37.0\% (Chintaco), 78.2\% (Irenedu), and $79.3 \%$ (Mozum). Significant variation $(p \leq 0.05)$ exists in the prevalence of the parasites in the fish species examined from the three locations (Table 7).

\section{Discussion}

This study showed a high parasitic infection in fish species from rivers Niger and Benue at Lokoja. This prevalence was higher than the prevalence of $59.2 \%$ observed in a study at Niger River at Illushi, Edo State [27], 17.1\% in Osse River, Benin, Nigeria [28], 6.9\% in Okhuo River, Benin, Nigeria [29], and 3.3\% in Great Kwa River, Calabar [16]. The high prevalence of infection in this study could be due the high level of pollutants accumulation as a result of long distance travelled by both rivers as well as the influx of pollutants from their several tributaries [30, 31]. Heavy parasitic infection in fish has been linked to environmental contamination by different pollutants including heavy metals and hydrocarbons [32] and organic enrichment of sediments by domestic sewage [33]. Other studies reported that urban effluents promote aquatic pollution, therefore making aquatic organisms vulnerable to increased incidence to parasites $[34,35]$. The high parasitic infection in this study might be due to the large influx of pollutants from the environment into the water bodies. Rohlenova et al. [36] reported that unfavourable temperature may alter fish physiology including immune function favouring parasite invasion. Other factors such as the behaviour and life history of the parasites and host fish might contribute to high parasitic infection [37].

A total of seven parasites species were found in fish samples from rivers Niger and Benue at Lokoja. Similar fish species were reported in a study carried out in Lake Gerio, Yola, Adamawa [15]; two of the parasites (Capillaria sp. and Contracaecum sp.) observed in this study were found in the Lake Gerio. Capillaria sp. was the second most prevalent parasite observed in their study with a prevalence of $16.7 \%$ higher than the prevalence of $10.5 \%$ observed in this study. Another study [38] on Clarias gariepinus in Owerri, Nigeria, reported the presence of Camallanus sp. (48.33\%) and Contracaecum sp. (11.67\%). In a study carried out on Clarotes laticeps, a fish species found in rivers Niger and Benue at Lokoja [18], they reported the presence of the Proteocephalus largoproglotis, Rhabdochona congolensis, and Contracaecum microcephalum alongside other parasites. The presence of the metacercariae of Clinostomum in the fish samples observed is an indicator of the presence of snails in the study sites which are the first intermediate hosts of parasites (Clinostomum). The metacercariae of Clinostomum is known to damage the muscles of fish, making it degusting and unsalable [39]. The high nematode parasites in fish host is an indication that the fish hosts feed on mud, debris, or detritus as found in most Clarias sp. and Synodontis sp. [40]. Hussen et al. [41] reported that helminths are mostly found in fresh water fishes where factors such as parasite species and its biology, host, and its feeding habitats, physical factors, hygiene of the water body, and presence of intermediate hosts contribute to their prevalence and intensity.

This study observed that female fish were more parasitized than male fish. Similar observation was reported in the studies by Mhaisen et al. [42], Ibiwoye et al. [43], and Amos et al. [15] that female fish are more infested than their male counterpart, while Biu et al. [44] disagree when they reported that variations in parasitic infection among the sexes of fish were by chance. Emere [45] reported differences 


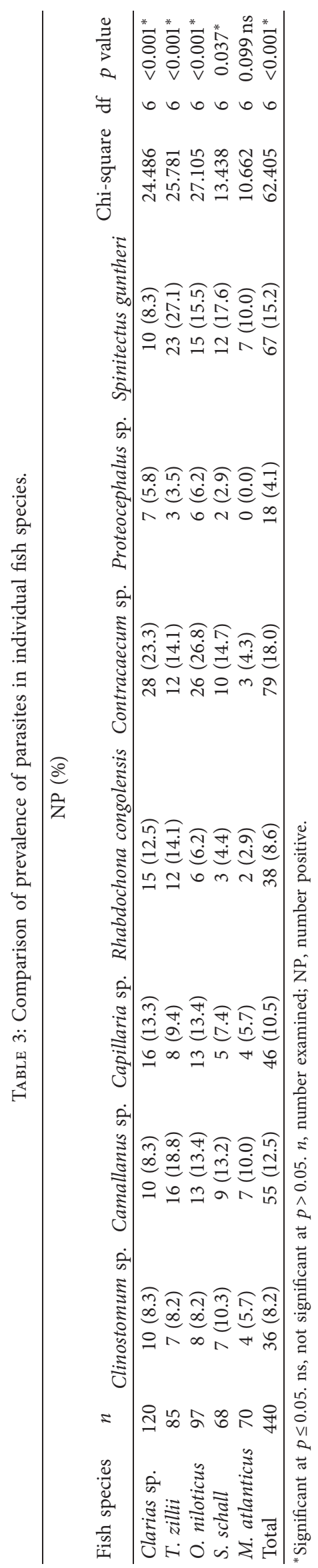


TABLe 4: Sex-specific prevalence of parasites in fish species in rivers Niger and Benue at Lokoja.

\begin{tabular}{|c|c|c|c|c|c|c|}
\hline Fish species & Sex & Number examined & Number positive & Chi-square & $\mathrm{df}$ & $p$ value \\
\hline \multirow{3}{*}{ Clarias sp. } & $\mathrm{M}$ & 48 & $32(66.7)$ & \multirow{3}{*}{8.889} & \multirow{3}{*}{1} & \multirow{3}{*}{$0.003^{*}$} \\
\hline & $\mathrm{F}$ & 72 & $64(88.9)$ & & & \\
\hline & & 120 & $96(80.0)$ & & & \\
\hline \multirow{3}{*}{ Tilapia zillii } & M & 44 & $42(95.5)$ & \multirow{3}{*}{0.005} & \multirow{3}{*}{1} & \multirow{3}{*}{$0.942 \mathrm{~ns}$} \\
\hline & $\mathrm{F}$ & 41 & $39(95.1)$ & & & \\
\hline & & 85 & $81(95.3)$ & & & \\
\hline \multirow{3}{*}{ Oreochromis niloticus } & $M$ & 50 & $44(88.0)$ & \multirow{3}{*}{0.319} & \multirow{3}{*}{1} & \multirow{3}{*}{$0.572 \mathrm{~ns}$} \\
\hline & $\mathrm{F}$ & 47 & $43(91.5)$ & & & \\
\hline & & 97 & $87(89.7)$ & & & \\
\hline \multirow{3}{*}{ Synodontis schall } & $M$ & 32 & $20(62.5)$ & \multirow{3}{*}{1.905} & \multirow{3}{*}{1} & \multirow{3}{*}{$0.168 \mathrm{~ns}$} \\
\hline & $\mathrm{F}$ & 36 & $28(77.8)$ & & & \\
\hline & & 68 & $48(70.6)$ & & & \\
\hline \multirow{3}{*}{ Megalops atlanticus } & M & 28 & $10(35.7)$ & \multirow{3}{*}{0.161} & \multirow{3}{*}{1} & \multirow{3}{*}{$0.688 \mathrm{~ns}$} \\
\hline & $\mathrm{F}$ & 42 & $17(40.5)$ & & & \\
\hline & & 70 & $27(38.6)$ & & & \\
\hline \multirow{3}{*}{ Overall } & M & 202 & $148(73.3)$ & \multirow{3}{*}{3.014} & \multirow{3}{*}{1} & \multirow{3}{*}{$0.083 \mathrm{~ns}$} \\
\hline & $\mathrm{F}$ & 238 & $191(80.3)$ & & & \\
\hline & & 440 & $339(77.0)$ & & & \\
\hline
\end{tabular}

* Significant at $p \leq 0.05$. ns, not significant at $p>0.05$.

TABle 5: Prevalence of parasites according to body parts of the fish species.

\begin{tabular}{|c|c|c|c|c|c|c|}
\hline Fish species & Body parts & Number examined & Number positive & Chi-square & df & $p$ value \\
\hline \multirow{3}{*}{ Clarias sp. } & Gills & 120 & $14(11.7)$ & \multirow{3}{*}{80.278} & \multirow{3}{*}{1} & \multirow{3}{*}{$<0.001^{*}$} \\
\hline & Intestines & 120 & $82(68.3)$ & & & \\
\hline & & 120 & $96(80.0)$ & & & \\
\hline \multirow{3}{*}{ Tilapia zillii } & Gills & 85 & $14(16.5)$ & \multirow{3}{*}{66.241} & \multirow{3}{*}{1} & \multirow{3}{*}{$<0.001^{\prime}$} \\
\hline & Intestines & 85 & $67(78.8)$ & & & \\
\hline & & 85 & $81(95.3)$ & & & \\
\hline \multirow{3}{*}{ Oreochromis niloticus } & Gills & 97 & $12(12.4)$ & \multirow{3}{*}{82.714} & \multirow{3}{*}{1} & \multirow{3}{*}{$<0.001^{*}$} \\
\hline & Intestines & 97 & $75(77.3)$ & & & \\
\hline & & 97 & $87(89.7)$ & & & \\
\hline \multirow{3}{*}{ Synodontis schall } & Gills & 68 & $8(11.8)$ & \multirow{3}{*}{32.970} & \multirow{3}{*}{1} & \multirow{3}{*}{$<0.001^{*}$} \\
\hline & Intestines & 68 & $40(58.8)$ & & & \\
\hline & & 68 & $48(70.6)$ & & & \\
\hline \multirow{3}{*}{ Megalops atlanticus } & Gills & 70 & $4(5.7)$ & \multirow{3}{*}{16.565} & \multirow{3}{*}{1} & \multirow{3}{*}{$<0.001^{*}$} \\
\hline & Intestines & 70 & $23(32.9)$ & & & \\
\hline & & 70 & $27(38.6)$ & & & \\
\hline \multirow{3}{*}{ Overall } & Gills & 440 & $52(11.8)$ & \multirow{3}{*}{264.985} & \multirow{3}{*}{1} & \multirow{3}{*}{$<0.001^{*}$} \\
\hline & Intestines & 440 & $287(65.2)$ & & & \\
\hline & & 440 & $339(77.0)$ & & & \\
\hline
\end{tabular}

* Significant at $p \leq 0.05$. ns, not significant at $p>0.05$.

TAвLE 6: Prevalence of fish parasites according to locations at rivers Niger and Benue, Lokoja.

\begin{tabular}{|c|c|c|c|c|c|c|}
\hline Sampling locations & $\begin{array}{c}\text { Number of fish } \\
\text { examined }\end{array}$ & $\begin{array}{c}\text { Number positive } \\
(\%)\end{array}$ & $\begin{array}{c}\text { Number negative } \\
(\%)\end{array}$ & $\begin{array}{c}\text { Chi- } \\
\text { square }\end{array}$ & df & $p$ value (ns) \\
\hline $\begin{array}{l}\text { Chintaco (downstream of } \\
\text { confluence) }\end{array}$ & 153 & $113(73.9)$ & $40(26.1)$ & \multirow{4}{*}{1.402} & \multirow{4}{*}{2} & \multirow{4}{*}{0.496} \\
\hline Irenedu (River Niger) & 142 & $111(78.2)$ & $31(21.8)$ & & & \\
\hline Mozum (River Benue) & 145 & $115(79.3)$ & $30(20.7)$ & & & \\
\hline Total & 440 & $339(77.0)$ & $101(23.0)$ & & & \\
\hline
\end{tabular}

ns, not significant at $p>0.05$. 
TABLE 7: Comparison of prevalence of parasites from different locations at rivers Niger and Benue, Lokoja.

\begin{tabular}{|c|c|c|c|c|c|c|c|c|}
\hline \multirow{2}{*}{ Fish species } & \multicolumn{2}{|c|}{$\begin{array}{l}\text { Chintaco (downstream of } \\
\text { the confluence) }\end{array}$} & \multicolumn{2}{|c|}{ Irenedu (River Niger) } & \multicolumn{2}{|c|}{ Mozum (River Benue) } & \multicolumn{2}{|c|}{ Total } \\
\hline & $\begin{array}{l}\text { Number } \\
\text { examined }\end{array}$ & $\begin{array}{c}\text { Number } \\
\text { positive (\%) }\end{array}$ & $\begin{array}{l}\text { Number } \\
\text { examined }\end{array}$ & $\begin{array}{c}\text { Number } \\
\text { positive (\%) }\end{array}$ & $\begin{array}{l}\text { Number } \\
\text { examined }\end{array}$ & $\begin{array}{c}\text { Number } \\
\text { positive (\%) }\end{array}$ & $\begin{array}{l}\text { Number } \\
\text { examined }\end{array}$ & $\begin{array}{c}\text { Number } \\
\text { positive (\%) }\end{array}$ \\
\hline Clarias sp. & 43 & $35(81.4)$ & 37 & $33(89.2)$ & 40 & $28(70.0)$ & 120 & $96(80.0)$ \\
\hline Tilapia zillii & 28 & $27(96.4)$ & 26 & $24(92.3)$ & 31 & $30(96.8)$ & 85 & $81(95.3)$ \\
\hline $\begin{array}{l}\text { Oreochromis } \\
\text { niloticus }\end{array}$ & 33 & $29(87.9)$ & 30 & $27(90.0)$ & 34 & $31(91.2)$ & 97 & $87(89.7)$ \\
\hline $\begin{array}{l}\text { Synodontis } \\
\text { schall }\end{array}$ & 22 & $12(54.5)$ & 26 & $19(73.1)$ & 20 & $17(85.0)$ & 68 & $48(70.6)$ \\
\hline $\begin{array}{l}\text { Megalops } \\
\text { atlanticus }\end{array}$ & 27 & $10(37.0)$ & 23 & $8(34.8)$ & 20 & $9(45.0)$ & 70 & $27(38.6)$ \\
\hline Total & 153 & $113(73.9)$ & 142 & $111(78.2)$ & 145 & $115(79.3)$ & 440 & $339(77.0)$ \\
\hline Chi-square & \multicolumn{2}{|c|}{35.220} & \multicolumn{2}{|c|}{33.905} & \multicolumn{2}{|c|}{25.535} & \multicolumn{2}{|c|}{85.560} \\
\hline df & \multicolumn{2}{|c|}{4} & \multicolumn{2}{|c|}{4} & \multicolumn{2}{|c|}{4} & \multicolumn{2}{|c|}{4} \\
\hline$p$ value & \multicolumn{2}{|c|}{$0.000^{*}$} & \multicolumn{2}{|c|}{$0.000^{*}$} & \multicolumn{2}{|c|}{$0.000^{*}$} & \multicolumn{2}{|c|}{$0.000^{*}$} \\
\hline
\end{tabular}

* Significant at $p \leq 0.05$.

in the incidence of infestation between male and female fish, which may be due to differential feeding either by quantity or quality of feed or as a result of different degrees of resistance to infection. Also, the increased rate of food intake by the female fish to meet their food requirements for the development of their eggs might have exposed them to more contact with the parasites $[17,46]$.

Studies by Paperna [47], Onwuliri and Mgbamena [48], and Oniye [49] have reported parasites of gills from different fish species. The prevalence observed in this study is lower than what was observed in River Kaduna [17] and $17.7 \%$ in Kano [50]. No study in Nigeria has reported parasites from the gills of freshwater fish examined in this study. Majority of the parasites observed in this study were from the gastrointestinal tracts (GIT). The prevalence of these GIT parasites was higher than what was observed in the studies of Anosike et al. [51], Oniye et al. [52], and Dankishiya and Zakari [53] who reported prevalence of $34.70 \%, 19.17 \%$, and $40.85 \%$, respectively.

\section{Conclusions}

Seven parasite species, namely, Clinostomum sp. (trematode), Camallanus sp. (nematode), Capillaria sp., Rhabdochona congolensis (nematode), Contracaecum sp. (nematode), Proteocephalus sp. (cestode), and Spinitectus guntheri, were found in the branchial chamber and gastrointestinal tracts of fish species from Niger and Benue rivers at Lokoja. Among the fish species examined, T. zillii (81 $(95.3 \%))$ had the highest prevalence, while others had prevalence of $87(89.7 \%), 96(80.0 \%), 48(70.6 \%)$, and 27 $(38.6 \%)$ in $O$. niloticus, Clarias sp., S. schall, and M. atlanticus, respectively, with prevalence of 191 (80.3\%) and $148(73.3 \%)$ in females and males, respectively. The gastrointestinal tract $(287,65.2 \%)$ had a significant difference in prevalence in comparison to the branchial chamber $(52(11.8 \%))$. This study did not observe the influence of physicochemical parameters on parasites assemblage in fish species in Benue and Niger rivers. Future studies to establish the relationship between the physicochemical parameters and parasites assemblage are highly encouraged.

\section{Abbreviations}

GIT: Gastrointestinal tracts.

\section{Data Availability}

The datasets used to support the findings of this study are available from the corresponding author upon request.

\section{Ethical Approval}

This study follows guidelines for the care and use of experimental animals established by the Animal Care and Use Committee of the Kogi State University, Anyigba, Nigeria, for the purpose of control and supervision of experiments on animals.

\section{Conflicts of Interest}

The authors declare that they have no conflicts of interest.

\section{Authors' Contributions}

A.E.O.-A. conceptualized the study. A.E.O.-A. and C.A.Y. developed methodology and performed formal analysis. A.E.O.-A., M.A.O., and C.A.Y. investigated the study and wrote the original draft. A.E.O.-A., M.A.O., L.A., C.A.Y., and G.E.-S.B. collected resources and reviewed and edited the article.

\section{Acknowledgments}

The authors extend their appreciation to the researchers supporting the project and Umm Al-Qura University, Makkah, Saudi Arabia. 


\section{References}

[1] M. N. Dawson, "Species richness, habitable volume, and species densities in freshwater, the sea, and on land," Frontiers of Biogeography, vol. 4, no. 3, pp. 105-116, 2012.

[2] J. J. Wiens, "Faster diversification on land than sea helps explain global biodiversity patterns among habitats and animal phyla," Ecology Letters, vol. 18, no. 11, pp. 1234-1241, 2015.

[3] A. J. Lymbery, S. J. Lymbery, and S. J. Beatty, "Fish out of water: aquatic parasites in a drying world," International Journal for Parasitology: Parasites and Wildlife, vol. 12, pp. 300-307, 2020.

[4] A. J. Reid, A. K. Carlson, I. F. Creed et al., "Emerging threats and persistent conservation challenges for freshwater biodiversity," Biological Reviews, vol. 94, no. 3, pp. 849-873, 2019.

[5] D. Dudgeon, "Multiple threats imperil freshwater biodiversity in the anthropocene," Current Biology, vol. 29, no. 19, pp. R960-R967, 2019.

[6] IUCN, The IUCN Red List of Threatened Species, Version 20193, IUCN Publications, Gland, Switzerland, 2019, http://www. iucnredlist.org.

[7] D. Dudgeon, A. H. Arthington, M. O. Gessner et al., "Freshwater biodiversity: importance, threats, status and conservation challenges," Biological Reviews, vol. 81, no. 2, pp. 163-182, 2006.

[8] A. H. Arthington, N. K. Dulvy, W. Gladstone, and I. J. Winfield, "Fish conservation in freshwater and marine realms: status, threats and management," Aquatic Conservation: Marine and Freshwater Ecosystems, vol. 26, no. 5, pp. 838-857, 2016.

[9] O. O. Ashade, O. M. Osinoye, and E. A. Kumoye, "Isolation, identification and prevalence of parasites in Oreochromis niloticus from three selected River system," Journal of Fisheries and Aquatic Science, vol. 8, no. 1, pp. 115-121, 2013.

[10] M. Y. Manbe, A. K. Mohammed, I. Abdulfatai, U. Muaz, and K. Hussaini, "Prevalence of protozoan parasites in some freshwater fishes of Dangana Lake Lapai, Niger State, Nigeria," International Journal of Veterinary Sciences and Animal Husbandary, vol. 5, no. 2, pp. 13-16, 2020.

[11] J. E. Eyo, V. C. Ejere, O. I. Aguzie, N. Ivoke, F. N. Ekeh, and N. E. Ezenwaji, "Parasitofauna of five freshwater fishes in a Nigerian freshwater ecosystem," Croatian Journal of Fisheries, vol. 72, pp. 17-24, 2014.

[12] S. Ravinchandran, G. Rameshkumar, and T. Balasubramanian, "Infestation of isopod parasites in commercial marine fishes," Journal of Parasitic Diseases, vol. 34, no. 2, pp. 97-98, 2010.

[13] A. M. El-Asely, E. A. Abd El-Gawad, E. I. Soror, A. A. Amin, and A. A. Shaheen, "Studies on some parasitic diseases in Oreochromis niloticus fish hatchery with emphasis to life stages," Journal of Advances in Veterinary Research, vol. 5, no. 3, pp. 99-108, 2015.

[14] T. E. Atalabi, A. O. Awharitoma, and F. O. Akinluyi, "Prevalence, intensity, and exposed variables of infection with acanthocephala parasites of the gastrointestinal tract of Coptodon zillii (Gervais, 1848) [perciformes: cichlidae] in Zobe Dam, Dustin-Ma Local Government Area, Katsina State, Nigeria," The Journal of Basic and Applied Zoology, vol. 79, no. 29, 2018.

[15] S. O. Amos, T. E. Eyiseh, and E. K. Michael, "Parasitic infection and prevalence in Clarias gariepinus in Lake Gerio, Yola, Adamawa State," MOJ Anatomy and Physiology, vol. 5, no. 6, pp. 376-381, 2018.
[16] A. P. Ekanem, V. O. Eyo, and A. F. Sampson, "Parasites of landed fish from Great Kwa River, Calabar, Cross River State, Nigeria," International Journal of Fisheries and Aquaculture, vol. 3, no. 12, pp. 225-230, 2011.

[17] M. C. Emere and N. E. L. Egbe, "Protozoan parasites of Synodontis clarias (a fresh water fish) in River Kaduna," The Best Journal, vol. 3, no. 3, pp. 58-64, 2006.

[18] J. E. Eyo and F. O. Iyaji, "Parasites of Clarotes laticeps (ruppell, 1832 siluriformes, bagridae) at rivers Niger and Benue confluence, Lokoja, Nigeria," Journal of Fisheries and Aquatic Science, vol. 9, no. 3, pp. 125-133, 2014.

[19] F. O. Iyaji and C. A. Yaro, "Endoparasitic helminths of Synodontis schall (Bloch and Schneider, 1801, Siluriformes, Mochokidae) at the Confluence of Niger and Benue Rivers, Lokoja, Nigeria," International Journal of Fisheries and Aquatic Studies, vol. 4, no. 5, pp. 30-35, 2016.

[20] F. O. Iyaji and C. A. Yaro, "Monthly occurrence of nematode parasites of Synodontis species from rivers Niger-Benue Confluence at Lokoja, Nigeria," International Journal of Fisheries and Aquatic Studies, vol. 4, no. 5, pp. 36-40, 2016.

[21] "Britanica. Kogi State," 2020, https://www.britannica.com/ place/Kogi.

[22] W. Reed, J. Burchard, and A. J. Hopson, Fish and Fisheries of Northern Nigeria, Ministry of Agriculture, Kaduna, Nigeria, 1967.

[23] B. D. Olaosebikan and A. Raji, Field Guide to Nigerian Freshwater Fishes, Federal College of Freshwater Fisheries Technology, New Bussa, Nigeria, 1998.

[24] T. S. Imam and R. A. Dewu, "Survey of Piscine ecto and intestinal parasites of Clarias sp. sold at Galadima road fish market, Kano metropolis, Nigeria," Bioscience Research Communication, vol. 22, no. 4, pp. 209-214, 2010.

[25] G. L. Hoffman, Parasites of North American Freshwater Fishes, Cornell University. Press, London, UK, 2nd edition, 1998.

[26] O. N. Pugachev, P. I. Gerasev, A. V. Gussev, R. Ergens, and I. Khotenowsky, Guide to Monogenoidea of Freshwater Fish of Palaeartic and Amur Regions, Ledizioni Ledipublishing, Milano, Italy, 2010.

[27] N. E. Oyedineke, U. Obi, P. U. Ofoegbu, and I. Ukogo, "Helminth parasites of some freshwater fish from River Niger at Illushi, Edo state, Nigeria," Journal of American Science, vol. 6, no. 3, pp. 16-21, 2010.

[28] C. E. Okaka and J. E. Akhigbe, "Helminth parasites of some tropical freshwater fish from Osse River in Benin, Southern Nigeria," Tropical Freshwater Biology, vol. 8, pp. 41-48, 1999.

[29] C. U. Edema, C. E. Okaka, I. P. Oboh, and B. O. Okogub, “A preliminary study of parasitic infections of some fishes from Okhuo River, Benin City, Nigeria," International Journal of Biomedical Health Science, vol. 4, no. 3, pp. 107-112, 2008.

[30] R. Lae, S. William, and A. M. Masosou, "Review of the present state of the environment: fish stocks and fisheries of River Niger, West Africa," in Proceedings of the Second International Symposium on the Management of Large Rivers for Fisheries: Sustaining Livelihoods and Biodiversity in the New Millenium, R. L. Welcome and T. Petr, Eds., vol. 1, pp. 199-227, Food and Agricuclture Organization of the United Nations, Bangkok, Thailand, 2004.

[31] D. W. Kelly, R. Poulin, D. M. Tompkins, and C. R. Townsend, "Synergistic effects of glyphosate formulation and parasite infection on fish malformations and survival," Journal of Applied Ecology, vol. 47, no. 2, pp. 498-504, 2010.

[32] C. Schludermann, R. Konecny, S. Laimgruber et al., "Fish macroparasites as indicators of heavy metal pollution in river 
sites in Austria," Parasitology, vol. 126, no. 7, pp. S61-S69, 2003.

[33] D. J. Marcogliese and D. K. Cone, "Myxozoan communities parasitizing Notropis hudsonius (cyprinidae) at selected localities on the St. Lawrence River, Quebec: possible effects of Urban effluents," The Journal of Parasitology, vol. 87, no. 5, pp. 951-956, 2001.

[34] R. A. Khan and J. Thulin, "Influence of pollution on parasites of aquatic animals," Advances in Parasitology, vol. 30, pp. 201-238, 1991.

[35] S. J. Kemp and J. R. Spotila, "Effects of urbanization on Brown trout Salmo trutta, other fishes and macroinvertebrates in valley creek, valley forge, Pennsylvania," The American Midland Naturalist, vol. 138, no. 1, pp. 56-68, 1997.

[36] K. Rohlenová, S. Morand, P. Hyršl, S. Tolarová, M. Flajšhans, and A. Šimková, "Are fish immune systems really affected by parasites? An immunoecological study of common carp (Cyprinus carpio)," Parasites \& Vectors, vol. 4, no. 120, 2011.

[37] A. H. Bichi and S. S. Dawaki, "A survey of the ectoparasites on the gills, skin and fins of Oreochromis niloticus at Bagauda fish farm, Kano, Nigeria," Bayero Journal of Pure and Applied Sciences, vol. 3, no. 1, pp. 83-86, 2010.

[38] U. O. Okoye, E. E. Nduph, and S. A. Adeleye, "A survey on endo-parasites of Clarias gariepinus in some selected fish farms in Owerri west local government area of Imo State, Nigeria," International Journal of Fisheries and Aquatic Studies, vol. 4, no. 5, pp. 624-631, 2016.

[39] Y. Sinare, M. Boungou, A. Oueda, A. Gneme, and G. B. Kabre, "Diversity and seasonal distribution of parasites of Oreochromis niloticus in semi-arid reservoirs (West Africa, Burkina Faso)," African Journal of Agricultural Research, vol. 11, no. 13, pp. 1164-1170, 2016.

[40] F. O. Iyaji, Parasites of siluriformes at River Niger-Benue Confluence, Nigeria, Ph.D. thesis, University of Nigeria, Nsukka, Nigeria, 2011.

[41] A. Hussen, M. Tefera, and S. Asrate, "Gastrointestinal helminth parasites of Clarias gariepinus (catfish) in Lake Hawassa Ethiopia," Scientific Journal of Animal Science, vol. 1, no. 4, pp. 131-136, 2012.

[42] F. T. Mhasisen, N. K. Al-Salim, and N. R. Khamees, "Occurrence of parasites of the freshwater mugilid fish Liza abu (Heckel) from Basrah, Southern Iraq," Journal of Fish Biology, vol. 32, pp. 525-532, 1988.

[43] T. I. I. Ibiwoye, A. M. Balogun, R. A. Ogunsisi, and J. J. Agbontale, "Determination of the infection densities of mud fish Eustrongylides. In Clarias gariepinus and Clarias anguillaris from Bida floodplain of Nigeria," Journal of Applied Sciences and Environmental Management, vol. 8, no. 2, pp. 39-44, 2004.

[44] A. A. Biu and G. J. Akorede, "Prevalence of endo-parasitized of Clarias gariepinus (Burchell 1822) in Maiduguri, Nigeria," Nigerian Journal of Fisheries and Aquaculture, vol. 1, no. 1, pp. 1-6, 2013.

[45] M. C. Emere, "Parasitic infection of the Nile prech (Lates niloticus) in River Kaduna," Journal of Aquatic Sciences, vol. 15, no. 1, pp. 34-45, 2000.

[46] S. Omeji, S. G. Solomon, and E. S. Idoga, "A comparative study of the common Protozoan parasites of Clarias gariepinus from the wild and cultured environments in Benue state, Nigeria," Journal of Parasitology Research, vol. 8, 2011.

[47] I. Paperna, Parasites Infections and Diseases of Fishes in Africa. An Update (IFA Technical Paper) (31), Food and Agriculture Organzation of the United Nation, Rome, Italy, 1996.
[48] C. O. E. Onwuliri and M. O. Mgbemena, "The parasite fauna of some fresh water fish from Jos, Plateau State, Nigeria," Journal of Applied Fisheries and Hydrobiology, vol. 2, pp. 33-37, 1989.

[49] S. J. Oniye, Studies on the parasites of the branchial chamber and alimentary canal of the fish family mormyridae in Zaria, Ph.D. thesis, Ahmadu Bello University. Zaria, Zaria, Nigeria, 2000.

[50] S. I. Haladu, "Prevalence of gills and gastrointestinal tract of mormyrus rume," M.Sc. thesis, Bayero University, Kano, Nigeria, 2003.

[51] J. C. Anosike, E. P. C. Omoregie, and I. E. Nweke, "A survey of helminth parasites of Clarias gariepinues in Plateau State, Nigeria," Journal of Aquatic Sciences, vol. 7, pp. 39-43, 1992.

[52] S. J. Oniye, D. A. Adebote, and O. I. Ayanda, "Helminths parasites of Clarias gariepinus (tuegels) in Zaria. Nig," Journal of Aquatics, vol. 19, no. 2, pp. 71-5, 2004.

[53] A. S. Dankishiya and M. Zakari, "Study on the gastrointestinal helminth parasites of Clarias gariepinus (Tuegels). in Gwagwalada, FCT, Nigeria," The Best Journal, vol. 4, no. 2, pp. 79-81, 2007. 